\title{
Environmental Awareness among Residents of Embabe and Impact on Biodiversity Conservation
}

\author{
Feizel Ayitey Aryee \\ Mphil Environmental Management, School Of Public Leadership \\ Stellenbosch University, Matieland, Stellenbosch, South Africa
}

\begin{abstract}
Biodiversity conservation is now a common phrase in most conferences and seminars. Most scientist and researchers are focused on the larger view of conserving our planet. Charity they say begins at home and also little drops of water make a mighty ocean. The conservation of our natural resource should start small by every community, town, municipality, city and then every country. This research work focused on a rural town called Embabe. Embabe is located in KwaZulu Natal, South Africa. The area is rich in plant and animal life. Having lived there for more than a year, I conducted this research to examine the level and willingness of the local community to conserve their biodiversity. I found out that, though majority of the resident are quit enlightened with regards to biodiversity conservation, they are however not willing to protect their rich natural resource. The main reason for this is poverty. Human beings are always thinking of satisfying our basic needs first before the environment. Government, Non-Governmental and other private agencies need to invest into poverty eradication in other to halt biodiversity destruction especially in rural areas.
\end{abstract}

Keywords: Biodiversity, Conservation, Natural Resource, Embabe, South Africa

\section{Introduction}

There is a general concern over environmental issues in the world now. Various organisations and government agencies are trying their best to cub this problem. In as much as environmental issues are of global concerns, the situation can be improved when it is dealt with locally.

Embabe is a rural community in Kwazulu-Natal, KZN; it is about $300 \mathrm{~km}$ away from Durban and close to KwamBonambi. Like a typical rural area in KZN, the area is not densely populated. There is a vast plants and animal diversity with houses interspersed. Many of the settlers engage in small scale farming like maize planting and cabbage cultivation. This is however done seasonally. Many of the settlers also have livestock such as cows, goats and fowls

Embabe is mostly in harmony with its environment but in ten years to come, will this rural area that is in harmony with its environment remain the same? This study intends to look at the environmental awareness among Embabe dwellers and how the future looks like in terms of biodiversity conservation and environmental degradation.

There is the need to ensure the conservation of our biodiversity because humans derive a lot of benefits from out biodiversity.

Many industrial materials derive directly from biological sources. These include building materials, fibres, dyes, rubber and oil. Biodiversity is also important to the security of resources such as water, timber, paper, fibre and food (World Business Council for Sustainable Development, Earthwatch Institute, 2007). As a result, biodiversity loss is a significant risk factor in business development and a threat to long term economic sustainability (WRI Corporate Ecosystem Service Review)

Biodiversity supports many ecosystem services that are often not readily visible. It plays a part in regulating the chemistry of our atmosphere and water supply. Biodiversity is directly involved in water purification, recycling nutrients and providing fertile soil. Experiments with controlled environments have shown that humans cannot easily build ecosystems to support human needs; for example insect pollination cannot be mimicked. Daisy wood simulation, supported by evidence from scientific studies, has proven the positive co-relation of biodiversity with ecosystem stability, protecting against disruption by extreme weather or human exploitation (Lovelock, 2000)

The following are the objectives for this research work

I. Environmental knowledge among residence of Embabe

II. Assessing the biodiversity of Embabe

III. The future of Embabe in terms of environmental degradation and biodiversity conservation 


\section{Literature Review}

The term biological conservation was first used by wildlife scientist and conservationist Raymond F. Dasmann in his 1968 lay book entitled 'A Different Kind of Country' (Dasmann, 1968), advocating conservation. Since this period the term has achieved widespread use among biologists, environmentalists, political leaders and concerned citizens

Biodiversity is the degree of variation of life forms within a given ecosystem, biome or an entire planet. Biodiversity is in part a function of climate. Rapid environmental changes typically cause mass extinctions. One estimate is that less than $1 \%$ of the species that have existed on earth are extant (Raup, 1994). Since life began on Earth, five major mass extinctions and several minor events have led to large and sudden drops in biodiversity. The Phanerozoic eon (the last 540 million years) marked a rapid growth in biodiversity via the Cambrian explosion - a period during which nearly every phylum of multicellular organisms first appear. In the Carboniferous, rainforest collapse led to a great loss of plant and animal life (Sahney et al., 2010). The PermianTriassic extinction event 251 million years ago was the worst; vertebrate recovery took 30 million years (Sahney et al., 2010). The most recent, the Cretaceous-Tertiary extinction event, occurred 65 million years ago and has often attracted more attention than others because it resulted in the extinction of the dinosaurs (Bambach, et al., 2004)

The period since the emergence of humans has displayed an ongoing biodiversity reduction and an accompanying loss of genetic diversity. Named the Holocene extinction, the reduction is caused primarily by human impacts, particularly habitat destruction. Conversely, biodiversity impacts human health in a number of ways, both positively and negatively (Sala, et al., 2009).

Biodiversity supports ecosystem services including air quality climate, water purification, pollination and prevention of erosion (Costanza et al., 1997). Non-material benefits include spiritual and aesthetic values, knowledge systems and the value of education. Biodiversity's relevance to human health is becoming an international political issue, as scientific evidence builds on the global health implications of biodiversity loss (Report of the $1^{\text {st }}$ and $2^{\text {nd }}$ International Conference on Health \& Biodiversity; Chivian, 2005). This issue is closely linked with the issue of climate change, (Climate Change and Biological Diversity, 2009) as many of the anticipated health risks of climate change are associated with changes in biodiversity (e.g. changes in populations and distribution of disease vectors, scarcity of fresh water, impacts on agricultural biodiversity and food resources etc.) This is because the species most likely to disappear are those that buffer against infectious disease transmission, while surviving species are those that increase transmissions such as that of West Nile Virus, Lyme disease and Hantavirus, according to a study done co-authored by Felicia Keesing, an ecologist at Bard College, and Drew Harvel, associate director for Environment of the Atkinson Center for Sustainable Future (ACSF) at Cornel University (Ramanujan, 2010)

The growing demand and lack of drinkable water on the planet presents an additional challenge to the future of human health. Partly the problem lies in the success of water suppliers to increase supplies, and failure of groups promoting preservation of water resources (Ramanujan, 2010). While the distribution of clean water increases, in some part of the world it remains unequal. According to 2008 World Population Data Sheet, Only $62 \%$ of least developed countries are able to access clean water (Population Bulletin, Vol.63). Some of the health issues influenced by biodiversity include dietary health and nutritional security, infectious diseases, social and psychological health (Gaston et al., 2007).

It is a highly accepted fact that biodiversity degradation has a negative effect on plant, animal and human life. There is therefore the need for us to ensure our plant and animal lives are protected to ensure the continuous existence of humans on earth. Since the 1960, activity of environmental movement has created awareness of the various environmental issues. There is no agreement on the extent of the environmental impact of human activity, and protection measures are often criticised.

In its broad sense, environmental protection may be seen to be the responsibility of all people and not simply that of government. Decisions that impact the environment will ideally involve a broad range of stakeholders including industry, indigenous groups, environmental groups and community representations. Gradually, environmental decision making processes are evolving to reflect this broad base of stakeholders and are becoming more collaborated in many countries (Harding, 2006). Biodiversity protection is determined by three interwoven factors, namely; environmental legislation, ethics and education. Each of these factors plays an important role in influencing national level and individual level environmental decisions. For biodiversity conservation to become a reality, it is important for societies to develop each of these areas. (Solomon, 2010).

It is very easy to proposed problems and solutions to biodiversity degradation, but the question will always arise; how do we implement these policies or proposals? African governments face several challenges in implementing environmental protection mechanisms. In Tanzania for example, these includes lack of financial resources to manage protected areas, poor governance and corruption, and significant illegal logging and hunting, (Pallangyo, 2007). Also with such large allocation of land to national parks, indigenous people have been forced to relocate what resulted in a lack of localparticipation in environmental decision making process. 
As a result of these factors recent calls have been made to allow 'parks with people' as a mean to encourage the support of better overall management and care of the land (Kantalawe et al., 2010).

iosrjestf@@gmail.com

\section{Collection of data}

\section{Methodology}

Questionnaires were issued out to residents of Embabe. The questionnaire was distributed strategically to make sure the information collated represents the view of the entire community. One hundred and seventy questionnaires were distributed and one hundred and thirty questionnaires were returned, representing about 76.47\%. It was written in English but was interpreted in Zulu for the locals by the help of grade 12 learners of Uyengo High School. The questionnaire targeted basically older people who have resided in the Embabe area for at least 10 years.

Pictures were taken at various locations of Embabe to have a clear and concise idea of the landscape of Embabe and its biodiversity distribution. The pictures were examined to know the exact biodiversity of the area. This was done because; pictures give a clear view than just looking at the landscape.

\section{Interpretation of Data}

The data collected with the aid of the questionnaires was graphically presented to give clear meaning. Graphs are able to be understood by many people than words, and many people are also likely to have a look at a graphical representation than read long essays

\section{Results}

Below is a summary of the results from the questionnaires that were distributed;

\section{Statisticsal Rsults}

Out of 170 questionnaires that were distributed, 130 were returned, representing $76.47 \%$ success. Below is a summary of the targeted groups

\begin{tabular}{|l|l|l|}
\hline Age groups & Number of People & Percentage \\
\hline $23-35$ & 38 & $29.23 \%$ \\
\hline $36-45$ & 23 & $17.69 \%$ \\
\hline $46-55$ & 76 & $58.46 \%$ \\
\hline $56-65$ & 10 & $7.69 \%$ \\
\hline $66-75$ & 7 & $5.38 \%$ \\
\hline TOTAL & $\mathbf{1 3 0}$ & \\
\hline
\end{tabular}

From the questionnaires distributed, $80 \%$ of age group $23-35$ did not have any knowledge of biodiversity conservation. Their main concern has to do with engaging in cabbage cultivation to make a living. $75 \%$ of those between $35-45$ did show some knowledge and concern for biodiversity conservation. They however are of the opinion that the government has to bear the full responsibility of protecting the biodiversity. The aged group between $46-75$ were considerate. $68 \%$ were very concern of their biodiversity. They recount the old years when they use to hunt for animals in the busy. I found out that they were more concern of conserving their biodiversity because they derive a kind of spiritual fulfilment from them. The typical zulu is very tradition and attributes spiritual motives to natural occurrences.

The pictures below are some of the pictures taken strategically at locations in Embabe, the site for this study 
Appendix 2; This picture shows one of the high schools in Embabe, Uyengo High School

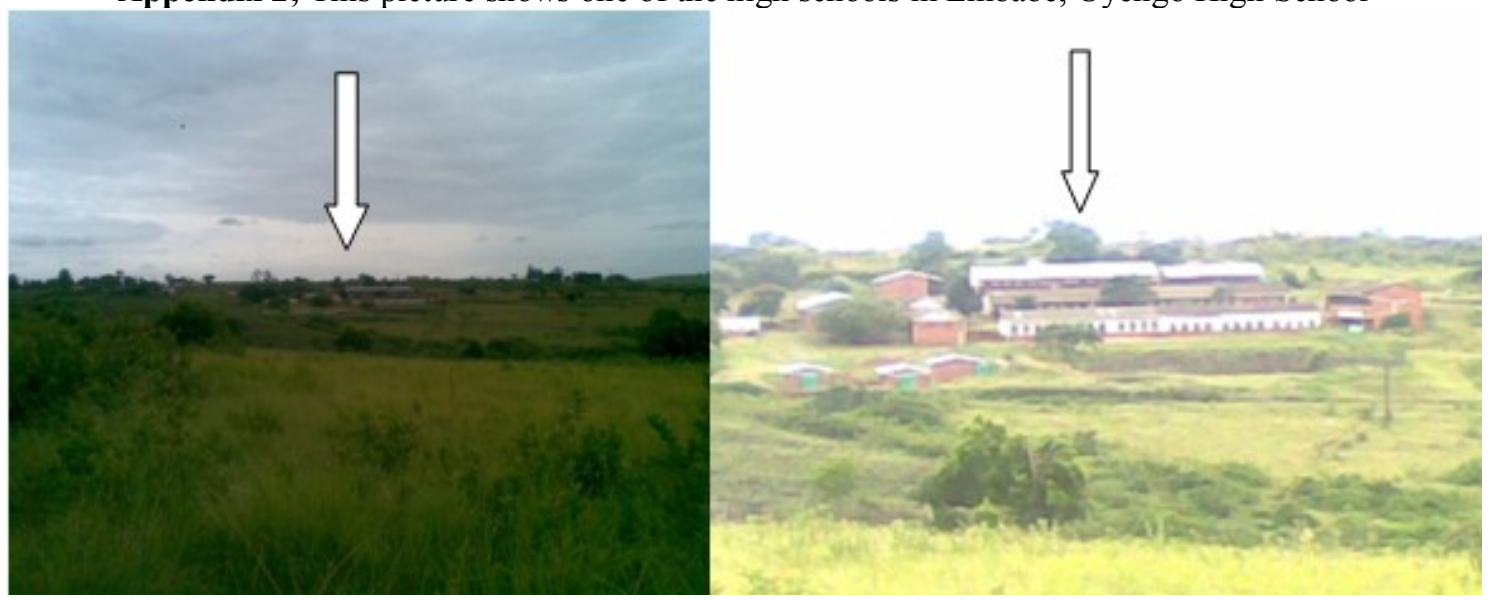

These two pictures were taken at the same location with different zoom angles. This shows how rich the area is in terms of plant life. There are virtually no houses around Uyengo High School and the only access to the school is the main road in front of the school.

Appendix 3; Few people in Embabe engages in subsistence farming

2a

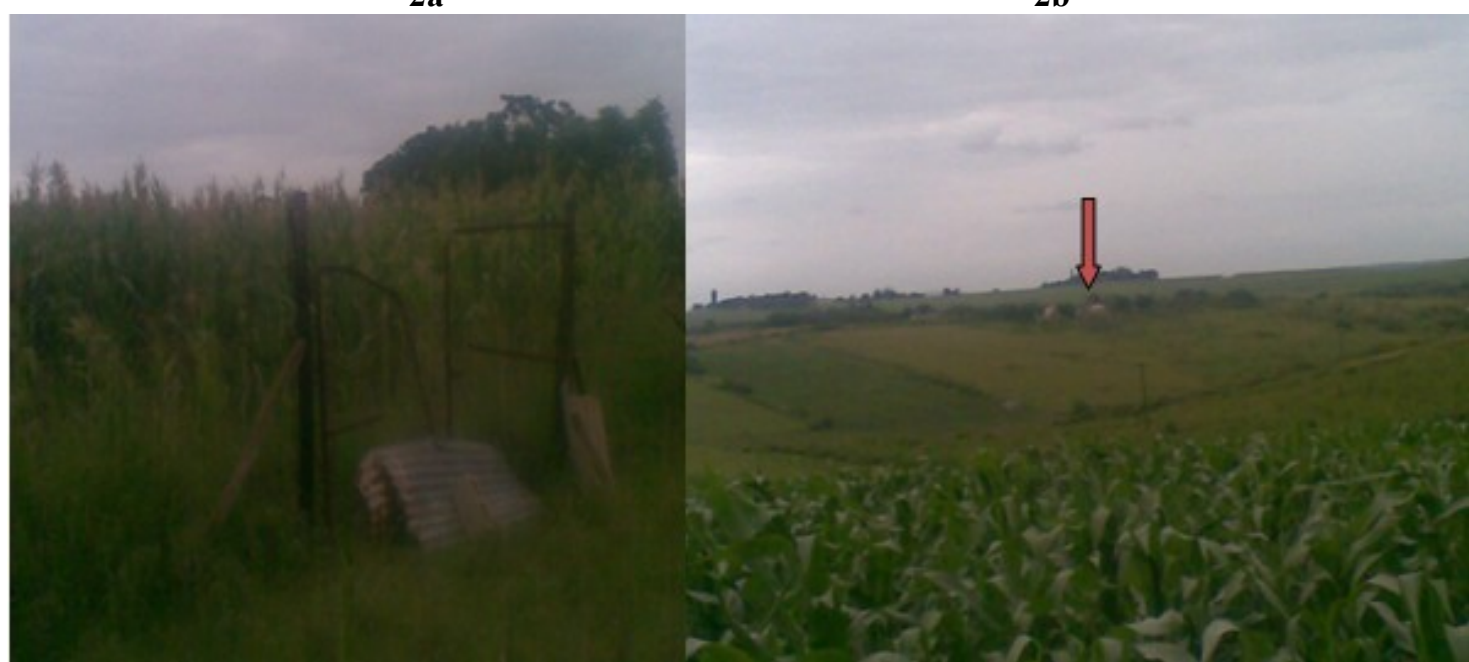

Figure $2 \mathrm{a}$ and $2 \mathrm{~b}$ shows maize farm. Only few of the residence engage in farming. Figure $2 \mathrm{a}$ shows a small maize farm which has been fenced to drive away fowls and other harmful pest. In figure $2 b$, the red arrow shows a house. This shows how far the people live from each other and how virgin the land is.

In as much as most of the land has not been touched yet, there are also human activities that adversely affect the biodiversity of the land and threaten plant and animal live as well as the health and welfare of resident of Embabe

Appendix 4: Pictures showing environmental degradation practices.

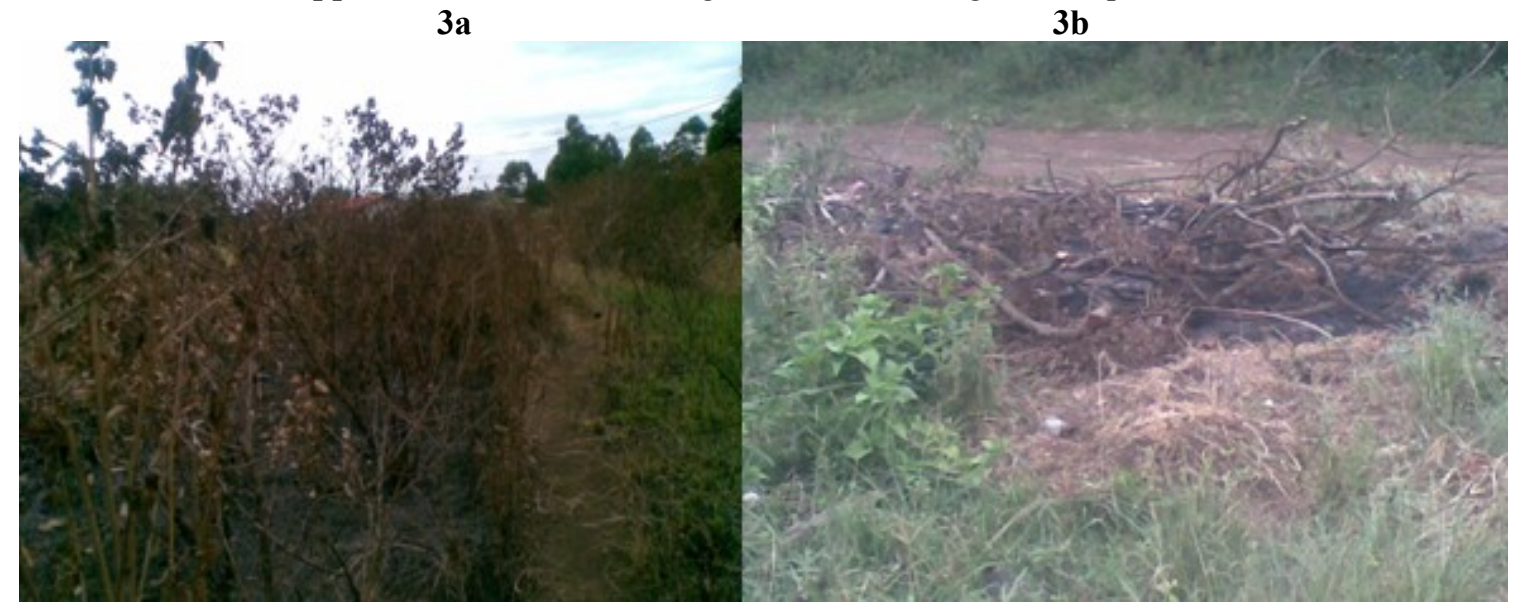




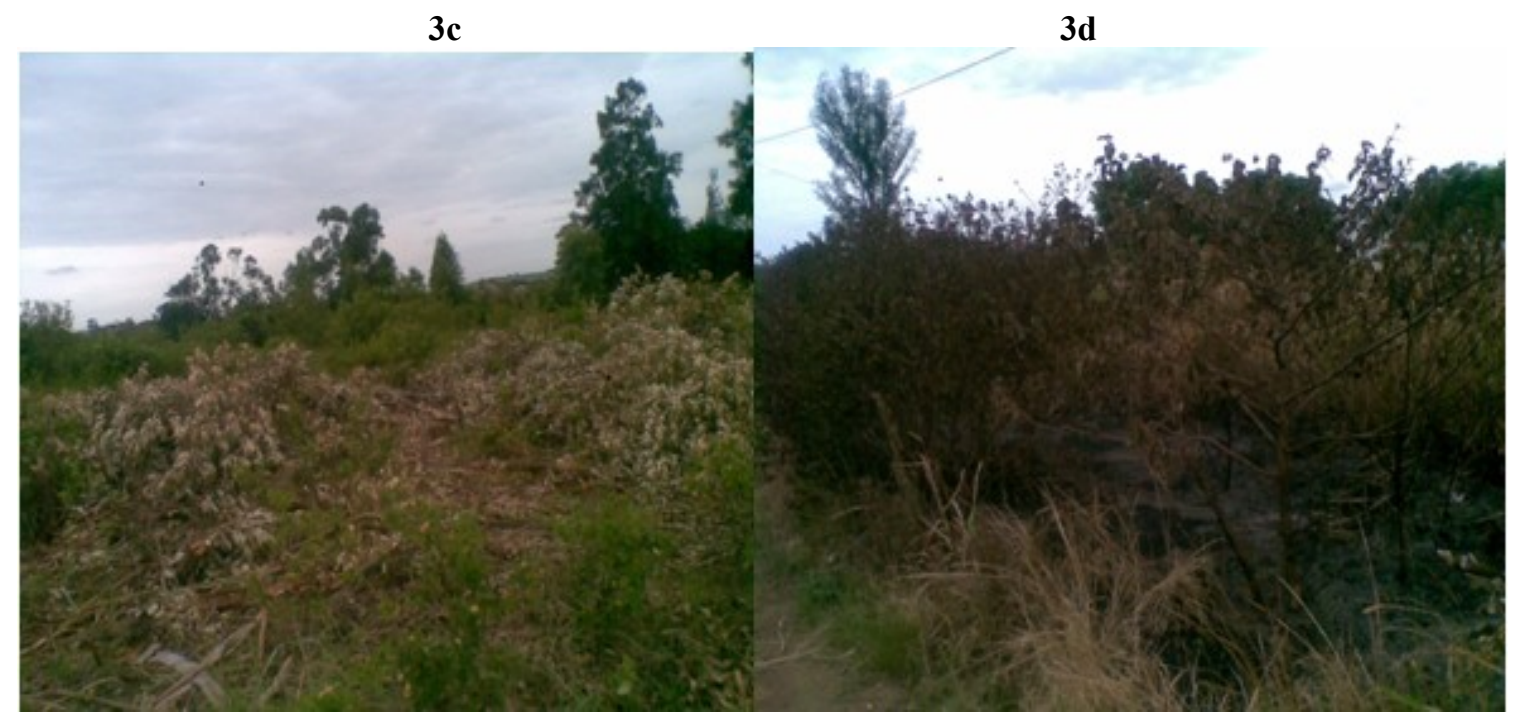

Appendix 5; Settlement lifestyle of residence of Embabe

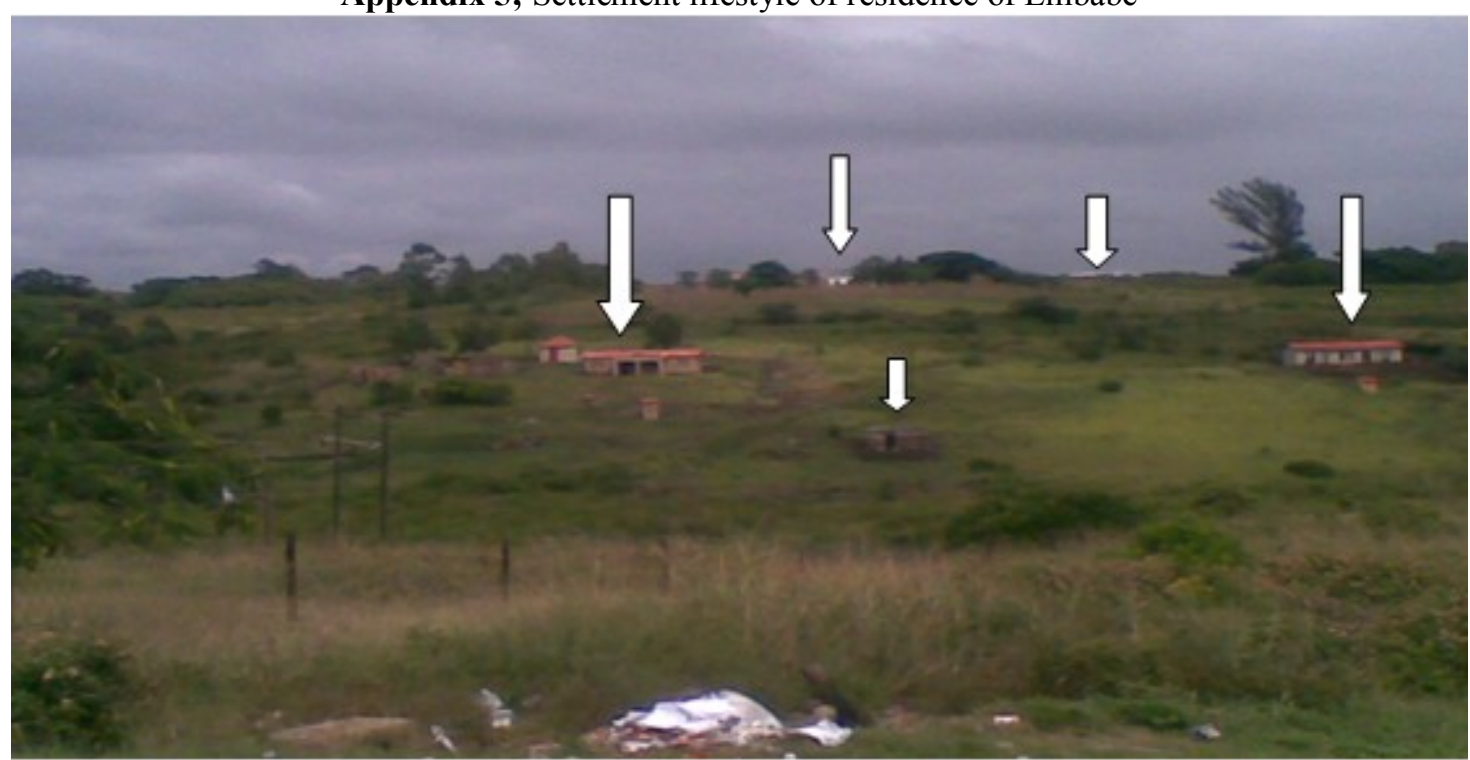

The picture above, depicts the settlement type in Embabe, It is a typical disperse type of settlement where various families live in isolation from one another, and in harmony with their environment. The white arrows show different houses interspersed in a particular area close to Uyengo High School

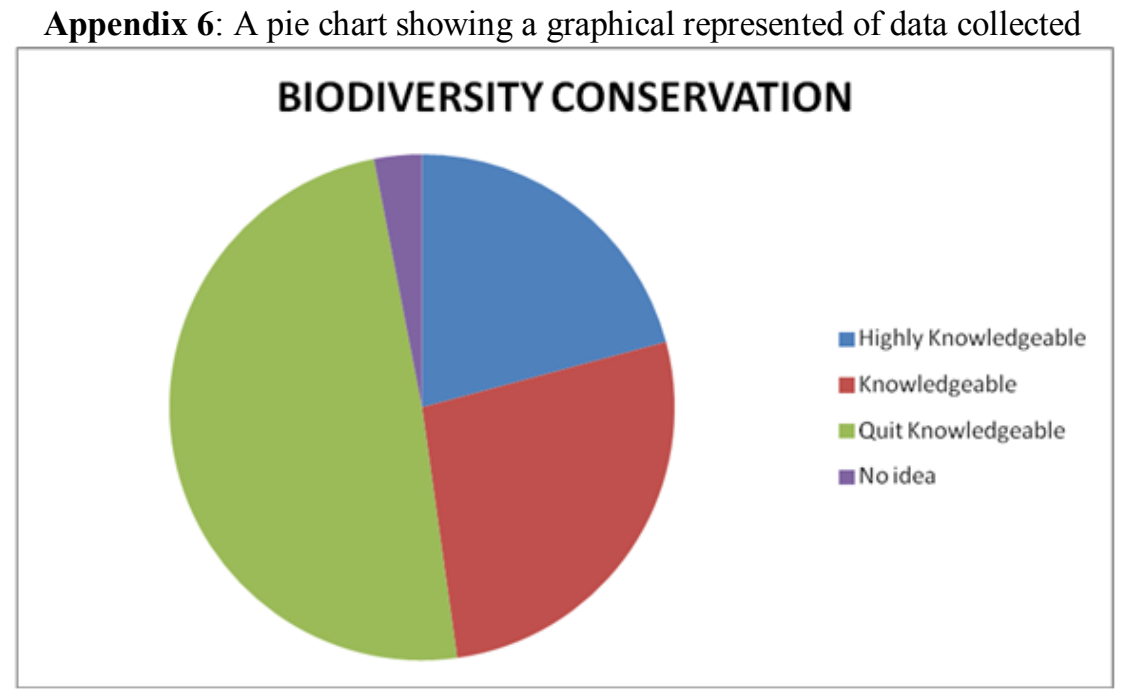


Appendix 7: Table representing data collected from questionnaire for the pie chat above.

\begin{tabular}{|l|l|l|}
\hline Parameters & Number of Households & Degree \\
\hline Highly Knowledgeable & 27 & $75^{\circ}$ \\
\hline Knowledgeable & 35 & $97^{\circ}$ \\
\hline Quite Knowledgeable & 64 & $177.23^{\circ}$ \\
\hline No idea & 4 & $11.1^{\circ}$ \\
\hline
\end{tabular}

\section{Discussion Of Results}

During the last century, decrease in biodiversity has been increasingly observed. In 2007, German Federation Environment Minister Sigmar Gabriel estimates that up to $30 \%$ of all species will be extinct by 2050 (Sigmar, 2007). Almost all scientists acknowledge that the rate of species loss is greater now than at any time in human history. With extinctions occurring at rates hundreds of times higher than background extinction rates.

From the pictures shown above, it can be seen that the Embabe area is very rich in terms of biodiversity with little human activities taking place in this vast area of land. The only interference is small scale maize farming and little burning of land. This clearly shows that the biodiversity of the area is still rich and virgin. Most of the older residents interviewed showed a lot of concern for the environment whiles the young generation seems unconcern about this whole biodiversity conservation issues; will this area remain the same in the next 10 or so year?

The worrying news is that, the younger folks (between 23 years -45 years) did not care about what is happening to their environment, even though they have an idea of what biodiversity conservation is. This is worrying because, the youth is the backbone of any community or country; therefore, if they show no concern for their environment, it means the environment is vulnerable to destruction in the not too far future. Embabe has a green environment and the indigenous locals have done their best in preserving this, however, if the youth are not bring on board, then the future looks very bleak in terms of biodiversity conservation of the area

From what I have seen so far in Embabe, the locals are very traditional in their way of life. I believe they derived so many intrinsic value from their environment; hence their concern for conservation of the biodiversity of plant and animal. The youth have however lost touch with their environment.

Most of them don't see the need to conserve the biodiversity of the area. One cannot however blame them entirely. My lecturer, Dave Pepler, always says that; one does not have the moral and ethical right to tell people who are hungry to conserve their biodiversity. Human beings need food first of all, after they are satisfy, then we can talk of biodiversity conservation.

The younger generation holds the future and if they do not see the need to conserve the biodiversity of the area, then am afraid, in the next 10 or more years, this nice serene area of Embabe may lose most of its biodiversity.

\section{Conclusion And Suggestion}

There are several approaches to solving environmental problems; the most popular ones are;

A) Voluntary environmental agreements: This is popular in industrialised or developed countries. Voluntary environmental agreements often provide the opportunity for companies to be recognised for moving beyond the minimum regulatory standards, thereby supporting the development of best environmental practices. (Karamanose, 2001). These agreements are commonly used to remedy significant level of non compliance with mandatory regulation. (Blackman, 2008)

B) Ecosystem approach; This approach aims to consider the complex interrelationships of an entire ecosystem in decision making rather than simply responding to specific issues and challenges. Ideally the decision-making processes under such an approach will be a collaborative approach to planning and decision making that involves a broad range of stakeholders across all relevant governmental departments, as well as representative of industry, environmental groups and community. This approach ideally supports a better exchange of information, development of conflict-resolution strategies and improved regional conservation (CIPA, 2011).

C) International environmental agreements; this is an attempt made by countries to develop agreements that are signed by multiple governments to prevent damage or manage the impacts of human activities on natural resources. This can include agreements that impact factors such as climate, oceans, river and air pollution. Some of the well-known multinational agreements include; the Kyoto Protocol, Vienna Convention on the Protection of the Ozone Layer and Rio Declaration on Development and Environment.

In my candid opinion, the best approach to solving the biodiversity destruction problem in Embabe is by using the Ecosystem approach. This approach is a holistic way of solving a problem. It involves the collaboration of governmental and non governmental agencies, private organizations as well as the locals themselves. Once the locals are involves, a compromise can easily be reached to help in the destruction of the environmental biodiversity in Embabe and it's environ. Involvement of the local residents in decision making also impacts a sense of responsibility in them. This will enable them show concern for their ecosystem destruction. 
The study draws attention to biodiversity conservation in Embabe, special attention was paid to the level of environmental awareness among residence of the area. About $90 \%$ of the people interviewed showed some level of awareness.

The main reason why the younger generation seems uninterested is because of poverty. It is highly inhuman to talk about environmental conservation while the ordinary person cannot afford a days' meal. It is logical human's wants to satisfy their basic needs first before any other thing according to the Maslow's' Theory of Needs.

In as much as the Embabe area has a rich biodiversity, in order to conserve this biodiversity, there will be the need to address first of all, the issue of poverty in and around this area and with that, the biodiversity of this beautify area will be conserve and it will go a long way in ensuing health and prosperity to this area in particular and the whole of South Africa in general.

The first principle of the Earth Charter (2000) starts with: 'Rest Earth and life in all its diversity, recognize that all beings are interdependent and every form of life has value regardless of its worth to human beings...'. From this, conservation is seen as giving voice to the voiceless. We humans, have the moral and ethical right to protect and co-exist with our environment, our environment here implying, plant, animal and the abiotic life forms. By living harmony with our environment, life on Earth will be sustained for the current and the future generation

Finally, I will end with the words of Theodore Roosevelt 'The conservation of natural resources is the fundamental problem. Unless we solve that problem, it will avail us little to solve all others'.

\section{References}

[1]. Bambach, R.K.; Knoll, A. H.; Wang, S. C. (2004). 'Origination, extinction, and mass depletion of marine diversity'. Paleobiology $30(4): 522-42$.

[2]. Blackman, A., (2008) Can Voluntary Environmental Regulation Work in Developing Countries? Lessons from Case Studies. Policy Studies Journal, 2008. 36(1): p. 119-141.

[3]. Chivian E. \& Bernstein A. (eds). 2008. Sustaining Life: How Human Health Depends on Biodiversity

[4]. Constanza, Robert; D’arge, Ralph; De Groot, Rudolf; Farber, Stephen; Grasso, Monica; Hannon, Bruce; Limburg, Karin; Naeem, Shahid et al (1997). 'The value of the world's ecosystem services and natural capita'. Nature 387 (6630): $253-260$

[5]. CIPA. 2001 An ecosystem approach to natural resource conservation in California 2001 (cited 201118 September). Available from: http://www.interenvironment.org/cipa/ecosystemapproach.htm

[6]. Dasmann, R.F. 1968. A Different Kind of Country. MacMillan Company. New York. ISBN 0-02-072810-7

[7]. Earth Charter, 2000. < http://www.earthcharterinaction.org/content/pages/Read-the-Charter.html > (accessed 19.02.09.).

[8]. Fuller, Richard A. (2007). 'Psychological benefits of greenspace increase with biodiversity'. Biology letters 3 (4): 390 - 394

[9]. Gabriel, Sigmar, 2007. '30\% of all species lost by 2050'. BBC News. 2007-03-09 (accessed 04.11.14)

[10]. Harding, R. 2006, Ecologically sustainable development: origin, implementation and challenges. Desalination, 2006. 187(1-3): p. 229-239

[11]. IUCN, WRI, Word Business Council for Sustainable Development, Earthwatch Inst. 2007 Business and Ecosystem: Ecosystem Challenges and Business Implications James Lovelock (2000). The ages of Gaia: a biography of our living Earth. Oxford University Press. pp. 213 - 216. ISBN 9780192862174. Retrieved $27^{\text {th }}$ June 2011

[12]. Kangalawe, R, and J. Lyimo, 2010. Populayion dynamics, rural livelihoods and environmental degradation: some experiences from Tanzania. Environmental, Development \& Sustainability. 2010. 12(6): p. 985-997.

[13]. Karamanos, P., 2001 Voluntary Environmental Agreements: Evolution and Definition of a New Enviornmental Policy Approach. Journal of Environmental Planning and Managment, 2001. 44(1): p. 67-84

[14]. Pallangyo, D.M. (2007). 'Environmental Law in Tanzania; How Far Have We Gone?' LEAD: Law, Environment \& Development Journal 3(1).

[15]. Ramanujan, Krishna, 2010. 'Study: loss of species is bad for your health'. ( 2 December 2010). Cornell Chronicle. Retrieved 20 July 2011.

[16]. Raup, D. M. (1994). 'The role of extinction in evolution'. Proceedings of the National Academy of Sciences 91 (15): $6758-6763$.

[17]. Sahney, S., Benton, M.J. \& Falcon-Lang, H.J. (2010). 'Rainforest collapse triggered Pennysylvanian tetrapod diversification in Euramerica"' (PDF). Geology 38 (12): 1079 - 1082.

[18]. Sala, Osvaldo E.; Meyerson, Laura A.; Parmesan, Camille, 2001. Biodiversity change and human health: from ecosystem services to spread of disease. Island Press. pp. 3 - 5. ISBN 9781597264976 . Retrieved $28^{\text {th }}$ June 2011

[19]. Solomon, U., 2010. A detailed look at the three disciplines; environmental ethics, law and education, to determine which plays the most critical role in environmental enhancement and protection. Environment, Development and Sustainability. 2010. 12(6): p. 1069-1080.

[20]. Climate Change and Biological Diversity' Conversion on Biological Diversity Retrieved November 5, 2009. From http://www.cbd.int/climate/. Accessed: 4.11 .14 